\title{
The Impact and Implications of COVID-19 on China's Service Trade
}

\author{
Xinyu $\mathrm{Hu}^{*}$ \\ School of Economics and Business Foreign Languages, Wuhan Technology and Business University, Wuhan, China \\ *Corresponding author. Email: 195384702@qq.com
}

\begin{abstract}
The trade in goods and services of countries around the world has been seriously affected by the outbreak of the Coronavirus(COVID-19 ). This paper aims to explore the differences in the impact of the COVID-19 epidemic on China's trade in services and goods, as well as the impact of different service trade patterns. Using data from China's Balance Of Payments from December 2019 to August 2020, it is found that China is more resilient in services trade than goods Trade, and the trade deficit in the transportation and tourism sectors has improved. The epidemic has brought losses to China's cultural services, international contracting projects and other fields, but it has brought new opportunities in the areas of digital economy and trade, online office and distance education, and international service outsourcing. In addition, it was also found that the COVID-19 epidemic has different impacts on different modes of service trade. Relatively speaking, service trade mode 1 has a smaller impact, while service trade mode 2 to 4 will be directly adversely affected.
\end{abstract}

Keywords: COVID-19, Service of Trade, Resilience, Modes of Service Trade, China.

\section{INTRODUCTION}

From the outbreak of the Coronavirus (COVID-19) pandemic since the end of 2019 to January 31, 2020, the World Health Organization announced the novel covid19 was an international public health emergency. So far, the epidemic has been under good control in China, but not well from a worldwide perspective. By March 26, 2020, the novel coronavirus pneumonia continues to spread in more than 199 countries and regions, which has greatly increased the risk of uncertainty and global recession. According to the latest data from a joint report released by 36 international organizations on the United Nations Conference on Trade and Development (UNCTAD), the coronal pandemic made the global trade value reduce by $3 \%$ in the first quarter of this year. The report of the Coordination Committee of Statistical Activities (CCSA) shows that the economic downturn is expected to intensify in the second quarter and global trade will encounter a $27 \%$ month-on-month decline.

\section{THE IMPACT OF THE COVID-19 ON SERVICE TRADE}

\subsection{Overall Scale of Trade Decreases But Resilience of Service Trader Is Better Than Goods Trade}

Resilience, also interpreted as flexibility by domestic scholars, refers to the ability of a system to maintain its stability and recover to the original state after encountering external impact $[1,2]$. Borchet and Mattoo (2009) found that the resilience of service trade is better than that of goods trade in response to the crisis [3].

Figure 1 shows From December 2019 to June 2020, the export of goods trade descended from US \$232. 481 billion to US $\$ 184$. 179 billion by March 2020, with a decrease of $20.7 \%$; then it began to recover slowly in April and reached US \$226. 104 billion in August. In the same period, the export of service trade dropped from US \$26. 08 billion in December 2019 to US \$18. 34 billion in May and began to rise, reaching US \$18. 06 billion by August 2020. During the pandemic period, the growth rate of China's trade in goods and services both showed a downward trend, but relatively speaking, 
the fluctuation in goods trade was larger than that in the service trade. Besides, China's imports of goods and services both decreased slightly in the same period, but the fluctuation of service trade was smaller.

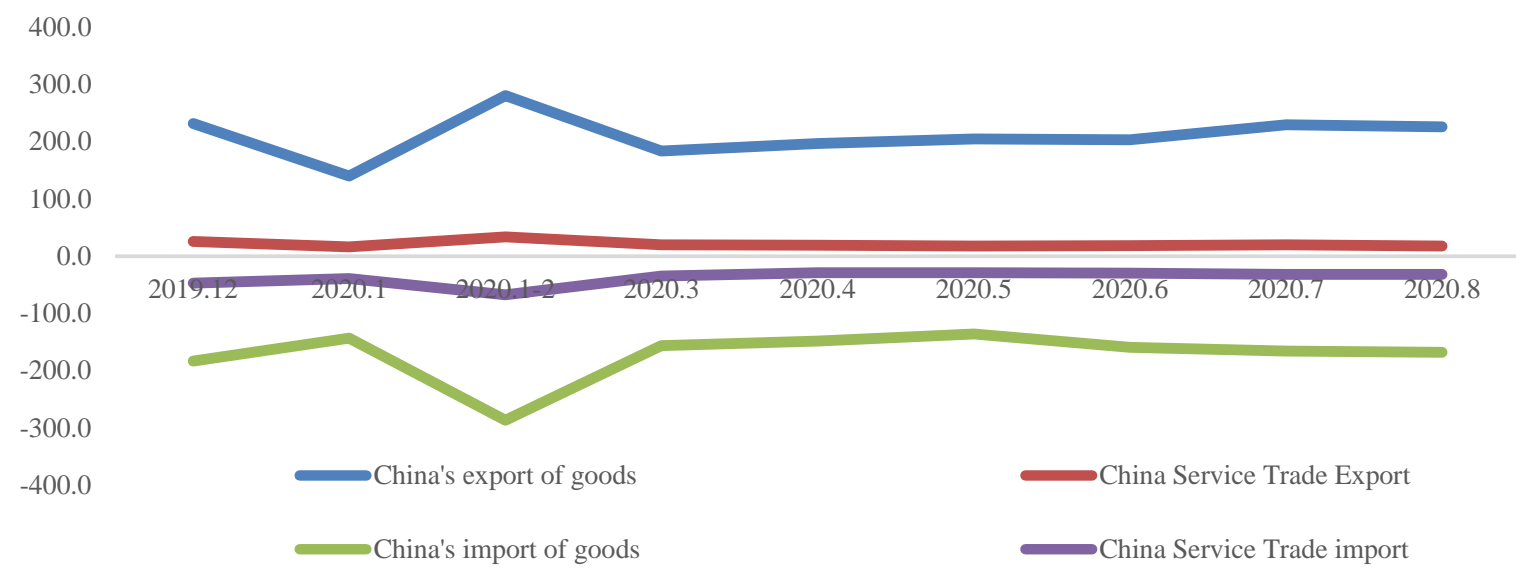

Figure 1. International trade in goods and services of China ( billions of dollars)

Source: State Administration of foreign Exchange: International trade in goods and services of China (updated to August 2020).

\subsection{Trade Deficit of Tourism and Transport Services Declined}

Due to the infestation of novel coronal pandemic around the world, many countries have taken measures to close the border, implement blockade or restrict tourism and trade, which have greatly affected the tourism service and transportation service in the service trade sector [4].

According to the data of China's service export from December 2019 to August 2020, the fluctuation of tourism services is the largest, followed by the transportation services. Among them, in 2019, the export of tourism service accounted for $14.76 \%$ and that of transportation service accounted for $19.02 \%$. Over the same period, imports of tourism service fell from US
$\$ 21.768$ billion in December to US \$7.6 billion in May 2020. In 2019, the import of tourism services accounted for $50.74 \%$ and that of transport service accounted for $20.96 \%$.

In terms of trade balance, the trade deficit of tourism service is decreasing(see Table1). About reasons, on the one hand, many foreign countries have imposed restrictive measures on outbound travel of Chinese tourists since February 2020. For example, from 5 p. m. on February 2, the United States has temporarily banned foreigners who have visited China in the past 14 days (except for immediate relatives of citizens and permanent residents of the United States) from entering the country. Similar regulations include that, over 100 countries or regions such as Singapore, Australia, Japan and Korea have temporarily suspended the direct flights

Table 1. International Trade in travel and transport services of china (billions of dollars)

\begin{tabular}{|c|c|c|c|c|c|c|}
\hline \multirow{2}{*}{ Item } & \multicolumn{3}{|c|}{ Travel service } & \multicolumn{3}{c|}{ Transport service } \\
\cline { 2 - 7 } & export & import & balance & export & import & balance \\
\hline Dec2019 & 2.98 & -21.77 & -18.79 & 4.63 & -9.87 & -5.23 \\
\hline Jan. 2020 & 2.40 & -20.74 & -18.35 & 3.251 & -7.86 & -4.61 \\
\hline Feb2020 & 3.41 & -33.43 & -30.02 & 6.7 & -14.32 & -7.62 \\
\hline Mar2020 & 1.20 & -12.72 & -11.52 & 3.57 & -7.67 & -4.09 \\
\hline Apr2020 & 1.22 & -8.40 & -7.18 & 4.42 & -7.07 & -2.65 \\
\hline May2020 & 1.38 & -7.60 & -6.22 & 4.96 & -6.67 & -1.72 \\
\hline Jun2020 & 1.62 & -8.40 & -6.78 & 4.667 & -7.73 & -3.06 \\
\hline Ju12020 & 1.78 & -9.79 & -8.01 & 4.92 & -8.87 & -3.95 \\
\hline Aug2020 & 1.80 & -10.58 & -8.78 & 4.47 & -7.92 & -3.46 \\
\hline
\end{tabular}

Source: State Administration of foreign Exchange: International trade in goods and services of China (updated to August 2020) 
between countries and the mainland of China. On the other hand, with the spread of novel coronavirus in foreign countries and after implementation of blockade measures in China, the epidemic situation has been better controlled and meanwhile the demand of Chinese citizens for outbound travel has also reduced. Hence, the import demand for tourism service is decreasing continuously. In the same period, the trade balance of China's transport service reached minus US \$5. 322 billion in December 2019 and minus US \$1. 717 billion in May 2020.

In the China's service trade industry, the transportation service is also a section with large trade deficit [5]. Under the epidemic situation, the reduction in China's goods trade directly led to the decline of transport services. In addition, due to the blockade measures adopted by other countries, flight were suspended and orders for ocean shipping were reduced sharply; in addition, the export of China's transport services descended from US \$4.633 billion in December 2019 to US $\$ 3.251$ billion in January 2020From February, the transport service showed a slow upward trend and increased to $\$ 4.955$ billion in May, which made China's trade deficit in transport services declined.

\subsection{Some Cultural Enterprises in Service Trade Field Suffered Losses}

According to the classification of WTO, the service trade field can be divided into 12 major categories and nearly 160 sub-categories. There are a large number of service sectors. However, the outbreak of novel coronavirus has caused different degrees of impacts on various service sectors. According to the statistics of the Ministry of Commerce, the total trade volume of China's cultural products reached $\$ 111.45$ billion in 2019 , with a year-on-year growth of $8.9 \%$; and the trade surplus reached $\$ 88.32$ billion, expanding by $6.8 \%$ in scale. From the perspective of countries and regions, ASEAN countries, EU countries and countries along the "Belt and Road" account for the larger proportion.

Industries which play an important role in the development of China's cultural industry such as film, performing-arts, have been negatively affected most by the epidemic. In accordance with the national film box office, the data showed that the box office of Spring Festival in 2019 was 5.905 billion, accounting for nearly $10 \%$ of the annual box office value. In 2020 , the box office of all kinds of institutions was predicted to exceed 10 billion, but the final data was only 23.57 million. The National Bureau of Statistics released the news on July 31 st that according to the survey of 59,000 scale culture and related industries and enterprises, all enterprises have achieved a business income of 16,889 billion yuan in the first quarter of 2020 , which was $13.9 \%$ lower than that of the same period last year on the comparable basis, but "Internet plus culture" showed an upward growth against the trend. Online consumption continued to grow rapidly. The 16 sub-categories of industry with obvious business characteristics have achieved the business revenue of 523.6 billion yuan, increasing by $15.5 \%$

\subsection{Decrease in Foreign Investment}

Facing the epidemic, many countries in the world have adopted blockade measures to deal with the challenges. In the manufacturing sector, many manufacturers close their factories, and upstream and downstream enterprises and enterprises in the related industry chain will inevitably be affected. The automobile, chemical, electronics, textile, metal and other industries in China, South Korea, and Japan are forced to reduce production or stop operations[6]. Economic activities such as international investment and international contracted projects, labor service cooperation, and transnational cultural and economic exchanges are all suspended.

The epidemic has also adversely affected multinational investment. The UNCTAD report pointed out: In the first half of 2020, all major forms of foreign direct investment in the world have declined. The UNCTAD report pointed out: The flow of foreign direct investment fell $49 \%$ year-on-year. Among them, Europe and the United States saw the largest declines.

According to statistics from the Ministry of Commerce of China, in the first quarter of 2020 , Chinese domestic investors made non-financial direct investments in 2,538 overseas companies in 153 countries and regions, with a total investment of RMB 169.03 billion, a year-on-year decrease of $0.6 \%$. The turnover of foreign contracted projects fell $12.4 \%$ yearon-year.

China has adopted some policy measures to respond. Since the beginning of this year, China has issued two new policies to stabilize foreign investment, released a new version of the negative list of countries and pilot free trade zones, established the Hainan Free Trade Port, and added 3 pilot free trade zones, and the business environment has continued to optimize.

\section{NEW OPPORTUNITIES BROUGHT BY THE COVID-19 EPIDEMIC}

\subsection{The Development Prospect of Digital Trade is Broad}

Baldwin (2012) classified trade into several stages including traditional trade stage, global value trade and digital trade stage. And digital trade consists of digital transactions of commodities and services delivered by digital or physical means [7]. 
From an economic point of view, the current inputs of production factors include not only capital, land, and labor, but also numbers. With the development of information and communication technology, China has entered the era of digital economy. The "China Digital Economy White Paper 2020" issued by the China Academy of Information and Communications Technology pointed out that China's digital economy accounts for $36.2 \%$ of GDP. In the field of digital economy, social media and search engines accelerate the expansion of overseas markets, and cloud services have become a new growth point. The scale and strength of public cloud service providers are second only to the United States, ranking second in the world.

After the resumption of work and production in China, more and more companies have shifted to digitalization or implemented digital strategies to enhance their competitiveness. For Chinese trading companies, cross-border e-commerce is developing rapidly. On June 11, 2020, Payoneer, an international payment service provider, released the first quarter global cross-border e-commerce index report. China's cross-border e-commerce revenue increased by $25 \%$ year-on-year, ranking first in the global cross-border ecommerce ranking.

Digital trade cannot achieve development without digital platforms. According to the Digital Economy Report in 2019 released by the United Nations Conference on Trade and Development (UNCTAD), it pointed out that, the seven super platforms, Microsoft, Apple, Amazon, Google, Facebook, Tencent and Alibaba, have gained strong market positions in different fields, which have accounted for about $2 / 3$ of the total market share. In 2017, the market value of these global 7 major digital trading platforms has reached at least $\$ 1$ billion [8]. In digital economy field, the United States and China keep playing the leading roles. These two countries account for $75 \%$ of the patents concerning blockchain technology, $50 \%$ of the global internet of things expenditure and more than $75 \%$ of the global public cloud computing market. So far, they have accounted for $90 \%$ of the market value of the world's top 70 largest digital platforms, where Europe only takes up $4 \%$ and Africa and Latin America only $1 \%$.

China has a huge domestic market. The epidemic has also changed people's consumption patterns, and online shopping has become a very convenient choice. China has hosted the 127th and 128th China Import and Export Commodities Fair online. The Palace Museum integrates digital resources. Visitors can view cultural relics, ancient buildings, exhibitions, and lectures anytime and anywhere through the official website of the Palace Museum and official WeChat. In addition, digital technology has played a major role in China's epidemic monitoring, virus traceability, and resource allocation.

\subsection{Demand for Online Office and Distance Education is Increasing}

Along with the adoption of preventive measures around the world, many enterprises and individuals switch to work at home and students start to take online lessons. Under the background, the demand for remote online video conference application is also increasing. According to Microsoft, users of its online office software have risen nearly $40 \%$ in a week [9]. In China, since the blockade measures came into effect at the end of January 2020, people's dependence on work applications such as Tencent conference, Wechat and Dingding are increasing. Due to the pandemic situation, the consumption preferences and habits of consumers are also changing. Demand for remote online medical treatment, shopping and entertainment is increasing, which also provides new opportunities for the development of digital platform providers in China. In addition, based on the concern degree of mainstream internet platforms, the Lanyue smart asset management team of WeBank has developed the online application to measure the industry public opinion index 16 , reflecting the prosperity and development trend of the industry. By means of calculation, it is found that the indexes of online office, online education and online games have increased significantly, respectively reaching 537\%, 169\% and $124 \%$ [10].

\subsection{Knowledge-intensive Service Trade Develops in Fast Pace}

According to the statistics of Ministry of Commerce of China, from January to August 2020, the import and export of knowledge intensive services reached 1317.39 billion yuan, with an increase of $8.5 \%$, and it accounts for $44.1 \%$ of the total import and import of services, with an increase of $10.1 \%$. Among them, the export of knowledge intensive services reached 692.89 billion yuan, with an increase of $8.5 \%$, and it accounts for $56 \%$ of the total export of services, with an increase of 5.5\%; The fields showing a faster export growth contained intellectual property use fees, telecommunications, computer and information services and insurance services, which respectively increased by $29.9 \%, 15.8 \%$ and $13.4 \%$. The import of knowledge intensive services reached 624.5 billion yuan, with an increase of $8.5 \%$, and it accounts for $35.6 \%$ of the total import of services, with an increase of $10.7 \%$; the fields showing a faster growth in import contained financial services, telecommunications, computer and information services and insurance services, which respectively increased by $26.7 \%, 25.3 \%$ and $20.1 \%$. It can be seen that knowledge intensive service trade has better resilience and strong impact resistance. Besides, it can better optimize the existing service trade structure of China, enhance the 
competitiveness of China's service trade and promote the high-quality development of China's service trade.

\subsection{Service Outsourcing Grows Against the Trend}

According to the statistics of the Ministry of Commerce of China, from January to August 2020, the contract amount of service outsourcing undertaken by Chinese enterprises reached $\$ 123$ billion and its implementation value reached $\$ 84.97$ billion, with an increase of $5.3 \%$ and $9.7 \%$ respectively on a year-onyear basis. Among them, the contract amount of offshore service outsourcing undertaken by Chinese enterprises was $\$ 73.25$ billion and its implementation value reached $\$ 51.65$ billion, with an increase of $3.4 \%$ and $10.7 \%$ respectively on a year-on-year basis. Meanwhile, as the advancement of "The Belt and Road" Initiative, the implementation value of Russian service outsourcing undertaken by China has increased by $56.9 \%$ year on year. In the service outsourcing field, with the development of digital economy, brand new business modes and patterns are emerging constantly, which also promotes the digital transformation of businesses and enterprises. Service outsourcing is also acting as an important part of China's service trade, which plays an essential role in alleviating the service trade deficit, expanding the export of service trade and improving the structure of service trade.

\section{THE ENLIGHTENMEN UNDER THE EPIDEMIC SITUATION}

\subsection{Mode 2 and Mode 4 in Service Trade have a more Direct Impact}

At present, the sudden outbreak of the new crown epidemic is still spreading globally, and some countries continue to implement control measures. Due to the suddenness, unpredictability and super-recognition of the outbreak of the epidemic, after the introduction of various control measures in various countries around the world, related services involving the movement of a large number of people, such as tourism services, transportation services (aviation control), export sharply decline.

According to the World Tourism Barometer Report released by the United Nations World Tourism Organization(UNWTO) on May 7,2020, it shows that, the scale of global cross-border tourism in the first quarter of this year has decreased by $22 \%$ year-on-year and the number of international tourists has decreased by 67 million person-time, resulting in a financial loss of $\$ 80$ billion .

In addition, due to the impact of the epidemic, world investment has also fallen sharply. From the perspective of the four types of service trade, the mode 2 overseas consumption, the mode 3 commercial presence, and the mode 4 movement of natural persons of the service trade are most directly affected by the epidemic, and the adverse effects are greater. In service trade mode 1 , cross-border delivery has less impact.

\subsection{Services Associated with Trade in Goods are also Greatly Affected}

Seen from the current external environment, especially in most countries such as the United States, the epidemic is still in the outbreak period. In terms of the global value chain, the global value chains in the service trade field with relative complexity such as automobiles, electronic products have broken or split, which have suffered great impacts by the epidemic situation and need to be rebuilt in the next few years. Although the China's trade deficit in transport services has been narrowed in the short term, those transport services closely related to goods trade will still be affected in the long run. For example, transportation and warehousing services, insurance services, customs declaration and inspection services, and freight forwarding services will all be affected. The development of these industries is not optimistic, especially in the first quarter of the epidemic. However, as the largest country in the trade of goods, the epidemic has also provided some new export opportunities. The export of epidemic prevention materials such as medical masks, disinfection supplies, and protective clothing has increased rapidly [11]. After the outbreak of the epidemic, many companies have transformed the production of medical anti-epidemic substances. For example, BYD Auto quickly adjusted to produce medical masks and exported them to the United States.

\subsection{The Epidemic has a Profound Impact on China's Service Industry}

Seen from the domestic environment, in the short term, China's service trade has been reduced and trade structure has obtained optimization, but the impact of pandemic situation on different service sectors can be different from each other. On the one hand, the outbreak of novel coronavirus has led to a certain adverse impact on the industries such as traditional tourism, catering, accommodation, transportation and cultural and entertainment services. On the other hand, it has also prompted these sectors to adjust structures and organizations, promote the improvement of service quality. In the long run, with the control of epidemic situation, these service sectors will gradually return to normality. Besides, the epidemic has also brought some new opportunities to China's foreign trade. In the field of digital trade, digital economy and service outsourcing, China has a solid foundation and advantages in aspects of digital platform, network users and high-quality talents. Thus, the significance of these 
fields during the epidemic period is getting increasing prominent [12].

\section{CONCLUSION}

The outbreak of the new crown epidemic has caused a greater impact on China's trade in goods and services. Using the data of China's trade in services and goods from December 2019 to August 2020, it is found that China's service trade is more resilient to the impact of the epidemic than trade in goods, and the fluctuation of service trade is smaller. However, the epidemic has shown different effects on different sectors of China's service trade. Among them, tourism services and transportation services are most affected. Due to the outbreak of the epidemic, it has brought a lot of negative effects on the tourism industry.

In addition, transportation services associated with trade in goods have a greater impact. However, from China's perspective, due to China's long-term huge trade deficit in tourism and transportation services, the implementation of control measures in various countries during the epidemic has reduced the trade deficit in these sectors and improved the structure of trade in services. The epidemic will have different impacts on different modes of service trade, among which modes 2 , 3 and 4 are more direct, while mode 1 has less impact.

Certainly, the outbreak of the novel coronary epidemic has a far-reaching impact not only on many sectors of service trade in China, but also on the service trade and economic development of various countries in the world. From the worldwide perspective, the outbreak of the epidemic has led to the economic recession, but it also provides a new opportunity for the development of digital economy and digital trade.

\section{REFERENCES}

[1] YonguiW,Jia G. Shocks of 2019-Ncov,Econmic Resilience and China's High Quality Development[J]. Journal of Economic Management, 2020, (5): 5-17. "in Chinese". DOI: 10.19616/j.cnki.bmj.2020.05.001.

[2] Aaron Zimba, Zhaoshun Wang, Luckson Simukonda. Towards Data Resilience: The Analytical Case of Crypto Ransomware Data Recovery Techniques[J]. International Journal of Information Technology and Computer Science, 2018, 1(8): 40-51, DOI: 10.5815/ijitcs.2018.01.05

[3] Borchert Ingo, Mattoo, Aadity. The crisisresilience of service trade[J]. Service Industries Journal, 2010, 30(13): 2115-2136. DOI: https://doi. org/10. 1080/02642060903289944.

[4] Qunhui H. Impact of COVID - 19 Epidemic on Supply Side and Countermeasures: Short-term and
Long-term Perspectives[J]. Journal of Econmic Review Journal, 2020, (5): 46-57. "in Chinese".DOI: 10.13658/j. cnki. sar. 2020. 03. 005.

[5] Nitin Singh Chauhan, Ashutosh Saxena, JVR Murthy. A Privacy-Aware Dynamic Authentication Scheme for IoT Enabled Business Services[J]. International Journal of Computer Network and Information Security, 2019, 6(8): 29-37, DOI: 10.5815/ijcnis.2019.06.04

[6] López González, J. and M. Jouanjean. Digital Trade: Developing a Framework for Analysis[C]. OECD Trade Policy Papers, 2017:.205. DOI:http://dx. doi. org/10.1787/ 524c8c83-en.

[7] Vimal Bibhu,Dhirendra Kumar Singh. Survey of MAC Layer Protocols for vehicular Ad Hoc Network[J]. International Journal of Information Technology and Computer Science, 2012, 3(9): 1118, DOI: 10.5815/ijitcs.2012.02.02

[8] UNCTAD.Digital Economy Report 2019:Value Creation and Capture Implications for Developing Countries[R]. United Nations Publications, 2020. https://unctad.org/webflyer/digital-economyreport- 2019.

[9] UNCTAD. The COVID-19 Crisis: Accentuating the Need to Bridge Digital Divides[R]. 2020. https: //unctad. org/webflyer/covid-19-crisis.

[10] The United Nations Development Programme Office in China. Assessment Report on Impact of COVID-19 Pandemic on Chinese Enterprises[R]. 2020.https://www.cn.undp.org/content/china/en/ho me/library/crisis_prevention_and_recovery/assess ment-report-on-impact-of-covid-19-pandemic-onchinese-ente.html.

[11] JinZh. Impact of the COVID - 19 Pandemic on China's Foreign Trade and the Countermeasures[J]. Journal ofInternational Trade, 2020, (7):9-15. "in Chinese". DOI:10.14114/j.cnki.itrade.2020.07.003

[12] YanxinC.The Impact of the new Crown Pneumonia Epidemic on my Country's Service Trade[J]. Journal of Import and Export Manager, 2020, (3): 17-19. "in Chinese". 